CZASOPISMO INŻYNIERII LA¿DOWEJ, ŚRODOWISKA I ARCHITEKTURY JOURNAL OF CIVIL ENGINEERING, ENVIRONMENT AND ARCHITECTURE JCEEA, t. XXXIV, z. 64 (3/II/17), lipiec-wrzesień 2017, s. 273-283, DOI:10.7862/rb.2017.171

\author{
Michał PROKSA ${ }^{1}$ \\ Monika ZUB ${ }^{2}$
}

\title{
EWANGELICKIE KOŚCIOŁY W TOMASZOWIE MAZOWIECKIM. PRÓBA ANALIZY PRZESTRZENNO-UŻYTKOWEJ I ARCHITEKTONICZNEJ
}

\begin{abstract}
Celem artykułu jest analiza przestrzenno-użytkowa i architektoniczna dwóch kościołów ewangelickich w Tomaszowie Mazowieckim: Św. Trójcy i Zbawiciela. Pierwszy z nich wybudowano w latach 20. XIX wieku w rynku lokowanego miasta, z chwilą przybycia ewangelików do nowo powstałej i rozwijającej przemysł włókienniczy osady. Zbudowano go na planie prostokąta z półowalną, pełniącą funkcję zakrystii kaplicą od północy. Bogato zdobiona południowa fasada zwrócona w stronę rynku posiada cechy klasycystyczne, a kanelowane pilastry dźwigające tympanon reprezentują prowincjonalną - w dobrym tego słowa znaczeniu - architekturę. Wnętrze z trzech stron obiegały empory wsparte na drewnianych kolumnach, co jest charakterystyczne dla przestrzeni świątyń ewangelickich. Niestety nie zachowało się pierwotne wyposażenie obiektu. Kościół był przeznaczony dla 400 wiernych, zwiększająca się ich liczba wymusiła zbudowanie nowego dużego kościoła przy ulicy św. Antoniego. W latach 1897-1899 wg projektu Pawła Hofera powstała nieorientowana (prezbiterium od północnego wschodu) neogotycka budowla pseudohalowa $\mathrm{z}$ jednowieżową fasadą wtopioną w bryłę kościoła między prostokątne kruchty. Trójprzęsłowy obiekt oszkarpowany dwuuskokowymi przyporami przekryto sklepieniami krzyżowymi i krzyżowo-żebrowymi oddzielonymi ostrołucznymi wąskimi gurtami. Elewacje zdobione są gzymsami, kolumienkami, ślepymi blendami, a w oknach spotyka się laskowanie, maswerki i elementy pięcioliścia. Porównując ten ewangelicki obiekt sakralny z innymi, podobnymi, katolickimi realizacjami neogotyckimi musimy powiedzieć, że pod względem programu przestrzenno-użytkowego i architektonicznego się nie różnią, może dekoracje wnętrza kościołów ewangelickich są skromniejsze, a ich najistotniejszym wyróżnikiem jest obecność empory nad nawami bocznymi.
\end{abstract}

Słowa kluczowe: architektura sakralna, klasycyzm, neogotyk, historyzm

\footnotetext{
${ }^{1}$ Autor do korespondencji/corresponding author: Michał Proksa, Politechnika Rzeszowska, Zakład Urbanistyki i Architektury, al. Powstańców Warszawy 12, 35-959 Rzeszów; tel.: 17865 1001; e-mail: mipro@prz.edu.pl

${ }^{2}$ Monika Zub, Politechnika Rzeszowska, Biblioteka, al. Powstańców Warszawy 12, 35-959 Rzeszów; tel.: 17743 2278; e-mail: mzub@prz.edu.pl
} 
Tomaszów Mazowiecki jest miastem młodym, o XIX-wiecznej genezie. Jego założycielem był Antoni hrabia Ostrowski, który starał się rozwijać przemysł włókienniczy na ziemiach dzisiejszej Polski Centralnej. Początkowo powstała tu, na surowym korzeniu, osada manufakturowo-handlowa, która 6 lipca 1830 roku otrzymała prawa miejskie. W organizowaniu centrum włókienniczego ulokowanego między Pilicą, Wolbórką, Czarną i Piasecznicą pomagali mu koloniści z Prus i ze Śląska, głównie wyznania ewangelickiego. Ich przybycie spowodowało tworzenie się tu struktur Kościoła Ewangelicko-Augsburskiego. W roku 1820 zawiązano kolegium kościelne, które wkrótce (1830 [4, s. 109]) przekształciło się w parafię. Pierwsze nabożeństwa organizowano w halach fabryk włókienniczych, później w zbudowanej sali tanecznej przez Antoniego Ostrowskiego [1], a prowadzili je dojeżdżający księża: Jerzy Wendt i Hoff.

$\mathrm{W}$ artykule tym przeprowadzimy analizę przestrzenno-użytkową i architektoniczną dwóch kościołów ewangelickich w Tomaszowie Mazowieckim: Św. Trójcy i Zbawiciela. Dokonamy jej przede wszystkim na podstawie własnych obserwacji oraz wykonanej dokumentacji fotograficznej, a uzupełnieniem naszych ustaleń będą informacje ze skromnej literatury i źródeł dotyczących obu obiektów, w tym tzw. białych kart zabytków [1, 5, 7], z których zaczerpnęliśmy plany obiektów oraz niektóre informacje faktograficzne.

Budowę pierwszego kościoła rozpoczęto w 1823 roku lokując go w północnej pierzei rynkowej (dziś Plac Kościuszki). Była to klasycystyczna budowla, którą w stanie surowym ukończono w 1824 roku (patrz data na elewacji budowli), ale wyposażanie trwało do 1829 roku [1]. Kościół dostał wezwanie Św. Trójcy, a pierwszymi administratorami byli Jan Jakub Benni i jego syn Herman [6, s. 9, 15; 3, s. 57]. W jego sąsiedztwie, w tej samej linii, oddzielonej dwoma wąskimi podjazdami, zbudowano szkołę i budynek pastoratu. Ściany wzniesiono z cegły i otynkowano, a kościół był pierwszą murowaną budowlą w mieście. Nie jest orientowany, założony na planie prostokąta $\mathrm{z}$ półowalną absydą od północy, która pełniła funkcję zakrystii (rys. 1.). Nakryto go dachem dwuspadowym krytym malowaną blachą cynkową założonym na drewnianej płatwiowo-jętkowej więźbie ze wzmocnieniami zastrzałami ścianek stolcowych [5]. Bogato zdobiona południowa fasada (rys. 2.) została podzielona na trzy części. Część środkowa flankowana jest parami pilastrów z poziomymi podziałami w tynku stojących na wspólnych, lekko profilowanych górą bazach, biegnących przez dwie kondygnacje, dźwigające belkowanie z płaskim fryzem i gzymsem kordonowym. Fasadę wieńczy szczyt schodkowy z podziałami w tynku, w formie prostej attyki, zdobiony kostkowymi kroksztynami, a pod nim po bokach dano dwie kwadratowe blendy. Nad szczytem postawiono wieżyczkę ze schodkową nasadą krytą blachą ,na karo”, zwieńczoną kulą i metalowym krzyżem. Na osi fasady przepruto główne wejście do świątyni ujęte kanelowanymi pilastrami dźwigającymi trójkątny tympanon. Nad nim umieszczono dwa otwory, niższy z promienistymi szczeblinami ujętymi niewielkimi pilastrami i wyższy będący blendą o kształcie leżącego prostokąta. Część środkową 
fasady wieńczy półkoliste okno z opaską, na której czole wyryto rzymskimi cyframi datę 1824, zapewne informującą o czasie zakończenia inwestycji w stanie surowym [9]. Autor białej karty [5] podaje nieprawdziwa datę 1823. Do wnętrza prowadzi przedsionek, wewnątrz znajdują się rzędy drewnianych kolumn dźwigających emporę ulokowaną od południa, wschodu i zachodu. Wnętrze doświetlają cztery osie przepruć okiennych z każdej strony bocznych elewacji, umieszczone na dwóch poziomach. Wyższe zamknięte półkoliście z cienką opaską, niższe również półkoliste ozdobiono imitacją nadproża wykonaną w tynku. Podobne okna dano w tylnej elewacji północnej, ale nad zakrystią umieszczono rozetę.

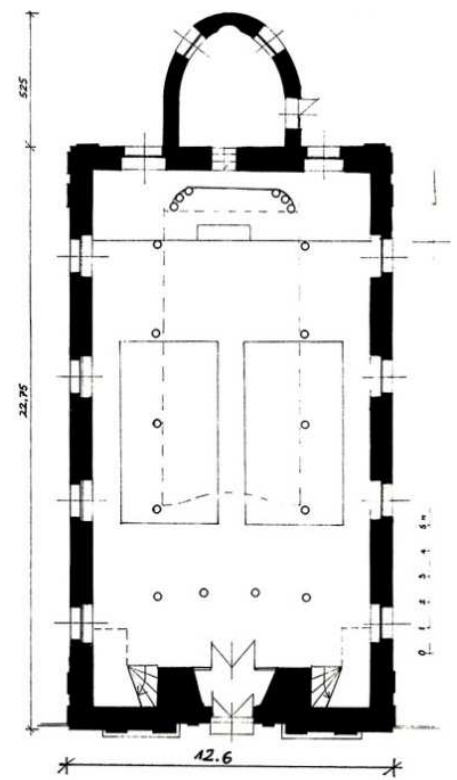

Rys. 1. Kościół św. Trójcy w Tomaszowie Mazowieckim - plan (źródło: [5])

Fig. 1. Church of the Holy Trinity in Tomaszów Mazowiecki - plan (source: [5])

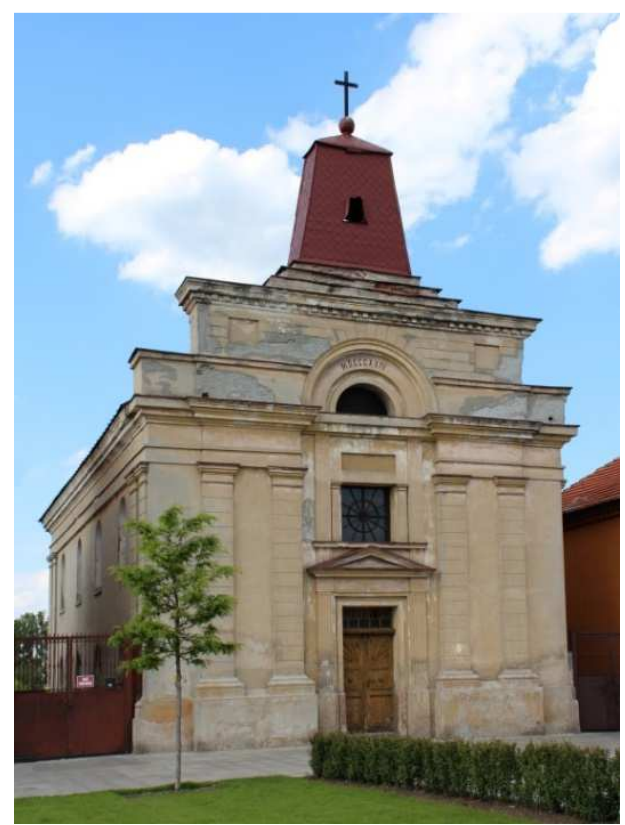

Rys. 2. Kościół św. Trójcy w Tomaszowie Mazowieckim - widok ogólny (fot. M. Zub)

Fig. 2. Church of the Holy Trinity in Tomaszów Mazowiecki - general viev (by M. Zub)

Z pierwotnego wyposażenia zachowało się niewiele. Są tu klasycystyczne organy z 1873 roku wykonane w Niemczech, a na osi nawy blisko zakrystii relikty neoklasycystycznego ołtarza. W zakrystii nie zachowało się oryginalne wyposażenie, a wiek dwóch rzędów ławek w nawie nie został ustalony [5].

Kościół św. Trójcy był przeznaczony dla 400 wiernych [5], a rosnąca ich liczba (w 1892 roku w mieście było 5506 luteranów) zmuszała do wybudowania nowej świątyni. [8, s. 373]. Zawiązany komitet budowy (Moritz Piesch, Karol 
Bartke, Mateusz Łuszczak, Jerzy Werner, Oskar Fürstenwald, Paweł Herkner, Gustaw Grossman, Daniel Krüger, Filip Krieg i Wilhelm Neubauer) zwrócił się do władz carskich o wydanie zezwolenia na realizację budowy [2], którą otrzymano w 1896 roku. Zakupiono plac przy ulicy św. Antoniego pod budowę o powierzchni około 1,5 ha, a ksiądz Eugeniusz Biedermann w połowie następnego roku odprawił nabożeństwo w intencji budowy. Projektantem obiektu był Paweł Hofer. Pracami kierował inż. Jan Wende, roboty nadzorował architekt Wilhelm Sroka [2], a inwestycje budowlane realizowała firma Stanisława Popławskiego [7]. Budowę zakończono w 1899 roku, a w latach 1899-1902 urządzano wnętrze. Kościół, zbudowany ze składek parafian (głównie Emmy Kramm) [2], otrzymał wezwanie Zbawiciela [2, 7].

Neogotycki ewangelicko-augsburski zespół sakralny składa się z kościoła [7], plebanii i budynków gospodarczych (stajnia z wozownią) [1]. Pamiętać też należy, że w mieście działała szkoła ewangelicka, wokół miasta zorganizowano kilka kantoratów, które posiadały własne domy modlitw.

W tym artykule podejmiemy jedynie próbę analizy przestrzenno-użytkowej i architektonicznej kościoła, natomiast pozostałe części zespołu opiszemy w innym miejscu. Podkreślmy, że sakralny ewangelicki zespół tomaszowski nie posiada monografii, a literatura go tycząca jest niewielka. Nasze opracowanie, choć krótkie i ogólne, jest pierwszym poświęconym temu obiektowi, jeśli oczywiście nie liczyć tzw. białych kart zabytków (obiekt został wpisany do rejestru zabytków pod numerem 436/8.10.1993 [1,7]).

Ewangelicki zespół sakralny w Tomaszowie Mazowieckim położony jest w południowej części miasta w odległości około $500 \mathrm{~m}$ od Rynku (dziś Plac Kościuszki), między ulicami: św. Antoniego, prostopadłymi do niej ulicami Tadeusza Seweryna i Szkolną oraz równoległą od północnego wschodu ulicą Bohaterów 14 Brygady. Po drugiej stronie ulicy św. Antoniego znajduje się park miejski. Od strony ulicy św. Antoniego działkę opasuje kute ogrodzenie żelazne na podmurówce, zaś od strony ulicy Tadeusza Seweryna ogrodzenie z elementów prefabrykowanych. Na działkę prowadzą dwie kute żelazne bramy (jedna z furtką) i furtka przy budynku plebanii dostępne od ulicy św. Antoniego, na osi bramy prowadzącej do kościoła znajduje się pamiątkowy kamień z napisem „Luteranie 1517-1917” [9]. W latach 1902-1904 w parku przyświątynnym nasadzono drzewa [1]

Kościół (rys. 3.) jest budowlą pseudohalową z emporami [9] (autor białej karty nazywa niesłusznie korpus budowli halą [7]). Zbudowany został z czerwonej cegły na zaprawie wapienno-cementowej, betonowy cokół ma wyraźny pulpitowy kołnierz, betonowy pulpit na profilowanym ceglanym gzymsie obiega cały korpus na poziomie parapetów okien górnej kondygnacji (gzyms kordonowy), wyżej znajduje się koronujący tynkowany gzyms profilowany. Dodatkowe zdobienie stanowią dekoracyjne elementy tynkowane (rys. 4.). Obiekt nie jest orientowany, ulokowane od północnego wschodu, nieznacznie niższe od korpusu prezbiterium [9] ma po obu stronach aneksy na planie leżących pro- 
stokątów [7]. W bryle świątyni widoczny jest trójdzielny transept (bez sygnaturki) [9], w jednowieżowej fasadzie po obu stronach wieży znajdują się prostokątne kruchty [7]. Obiekt jest w zasadzie jednorodny stylistycznie, choć kapitele kolumn mogą świadczyć o dalekich reminiscencjach barokowych, a biforia, triforia i fryz kolumnowy [9] świadczą o wątkach romańskich.

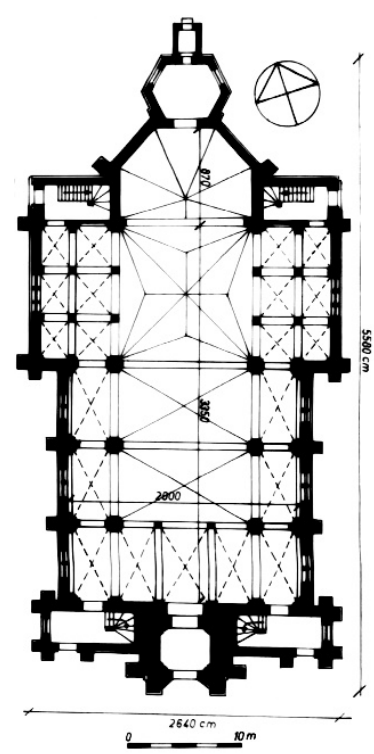

Rys. 3 Kościół Zbawiciela w Tomaszowie Mazowieckim - plan (źródło: [7])

Fig. 3 The Saviour's Church in Tomaszów Mazowiecki plan (source: [7])

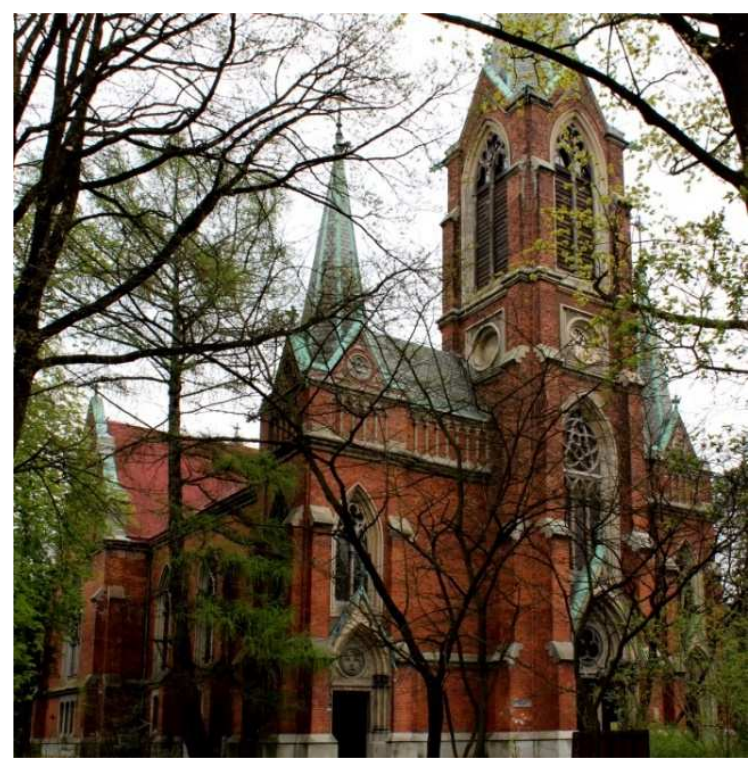

Rys. 4. Kościół Zbawiciela w Tomaszowie Mazowieckim - widok ogólny (fot. M. Zub)

Fig. 4. The Saviour's Church in Tomaszów Mazowiecki general viev (by M. Zub)

Korpus nawowy oskarpowanyjest dwuuskokowymi szkarpami z betonowymi pulpitowymi kapnikami. W nawie głównejma dwa przęsła na planie leżących prostokątów, odpowiadają im po dwa przęsła na planie prostokątów stojących w przyziemiu naw bocznych. Przęsło podchórza ma pięć przęseł na planie stojących prostokątów, zaś na nadchórzu podział odpowiada pozostałym przęsłom korpusu: nad nawą główną jest to leżący prostokąt, nad bocznymi prostokąty stojące $[9,7]$. Komunikację międzynawową w przyziemiu zapewniają arkady o odcinkowym zamknięciu, umieszczone między masywnymi filarami wiązkowymi, mocno profilowanymi, o bogato zdobionych kompozytowych kapitelach z motywami liści, na których spoczywają wiązki żeber sklepiennych. Nad arkadami znajdują się empory obiegające korpus, doświetlone dużymi 
ostrołucznymi oknami. Część pod emporami doświetlają biforia, a pionowe podziały ścian tworzą wiązkowe filary przyścienne [9]. Zagadnienia konstrukcyjne i szczegółowa charakterystyka elementów architektonicznych korpusu nawowego przedstawia (tab. 1.).

Tabela 1. Kościół Zbawiciela w Tomaszowie Mazowieckim. Charakterystyka korpusu nawowego

Table 1. The Saviour's Church in Tomaszów Mazowiecki. Characteristic of the body

\begin{tabular}{|c|c|}
\hline $\begin{array}{c}\text { Elementy } \\
\text { architektoniczne }\end{array}$ & Opis \\
\hline $\begin{array}{l}\text { Przekrycie nawy } \\
\text { głównej }\end{array}$ & $\begin{array}{c}\text { sklepienie krzyżowo-żebrowe, przęsła oddzielone ostrołucznymi wą- } \\
\text { skimi gurtami [9] }\end{array}$ \\
\hline $\begin{array}{l}\text { Przekrycie naw } \\
\text { bocznych }\end{array}$ & $\begin{array}{c}\text { sklepienia krzyżowo-żebrowe; w podchórzu i pod emporami krzyżowe } \\
{[9]}\end{array}$ \\
\hline $\begin{array}{l}\text { Konstrukcja i pokrycie } \\
\text { dachu nawy głównej }\end{array}$ & $\begin{array}{l}\text { więźba drewniana kleszczowo-płatwiowa ze słupem i dodatkową jętką w } \\
\text { górnej partii [7]; wspólny dach dwuspadowy kryty blachą ocynkowaną [9] }\end{array}$ \\
\hline $\begin{array}{l}\text { Konstrukcja i pokrycie } \\
\text { dachu naw bocznych }\end{array}$ & $\begin{array}{l}\text { więźba drewniana kleszczowo-płatwiowa ze słupem i dodatkową jętką w } \\
\text { górnej partii [7]; wspólny dach dwuspadowy kryty blachą ocynkowaną [9] }\end{array}$ \\
\hline Dekoracja ścian & $\begin{array}{c}\text { ściany otynkowane malowane na kremowo; bogato zdobione kapitele } \\
\text { kolumn; pełna balustrada empory zdobiona fryzem arkadkowym o } \\
\text { ostrym zamknięciu spoczywającym na mocno profilowanym gzymsie, } \\
\text { od góry również ujętym profilowanym gzymsem; elementy arkadkowe } \\
\text { co kilka pól zdobione wątkami trójliścia [9] }\end{array}$ \\
\hline Dekoracja sklepień & żebra sklepienne zaakcentowane brązowym kolorem [9] \\
\hline Okna naw bocznych & $\begin{array}{l}\text { duże okna o ostrym zamknięciu umieszczone w profilowanym tynko- } \\
\text { wanym rozglifieniu ujętym ceglaną oprawą, podzielone piaskowcowym } \\
\text { słupkiem na dwie części o dodatkowych ostrych zamknięciach i prostej } \\
\text { dekoracji maswerkowej; w głównym zamknięciu nad słupkiem znajduje } \\
\text { się dekoracja maswerkowa w kształcie czterolistnej koniczyny; masywny } \\
\text { szeroki tynkowany parapet umieszczony w ciągu profilowanego gzymsu } \\
\text { obiegającego cały korpus; pod nimi w przyziemiu małe okna w formie } \\
\text { biforiów, w oprawie piaskowcowej, z ukośnymi, prawie pionowymi para- } \\
\text { petami, o zamknięciach odcinkowych, postawione na kołnierzu cokołu [9] }\end{array}$ \\
\hline Witraże & $\begin{array}{c}\text { barwne witraże przedstawiają sceny i postacie biblijne; w części ma- } \\
\text { swerkowej barwne szkło o motywach geometrycznych; barwne szybki } \\
\text { wstawione również w niektórych biforiach; ramy żelazne, szkło w } \\
\text { armaturze ołowiowej [9]; witraże wykonane zostały w latach 1900-1903 } \\
\text { przez firmę H. Schlein z Zittar, a fundatorami były rodziny Fibel, } \\
\text { Knothe, Grossman, Britzman, Augspach, Meyer, także inż. Jan Wende } \\
\text { i członek komitetu budowy Moritz Piesch [1] }\end{array}$ \\
\hline
\end{tabular}

Jednoprzęsłowe, pięciobocznie zamknięte prezbiterium ma szerokość równą szerokości nawy głównej. Po obu jego bokach znajdują się prostokątne aneksy ze schodami prowadzącymi na emporę i do piwnicy, a na przedłużeniu dawna sześcioboczna zakrystia $\mathrm{z}$ prostokątnym przedsionkiem. Ostro zamknięty łuk tęczowy akcentuje komunikację z korpusem budowli, w północno-wschodnich ramionach transeptu przez znajdują się prostokątne otwory drzwiowe w profilo- 
wej tynkowanej ramie prowadzące do zakrystii. Prezbiterium nie zostało oszkarpowane, a dekorację elewacji stanowi betonowy cokół z fartuchem i profilowany koronujący gzyms tynkowany [9]. Szczegółowa charakterystyka architektoniczna tej części świątyni (tab. 2.).

Tabela 2. Kościół Zbawiciela w Tomaszowie Mazowieckim. Charakterystyka prezbiterium

Table 2. The Saviour's Church inTomaszów Mazowiecki. Characteristic of the choir

\begin{tabular}{|c|c|}
\hline $\begin{array}{l}\text { Elementy } \\
\text { architektoniczne }\end{array}$ & Opis \\
\hline Szczyt & trójkątny z wimpergą [9] \\
\hline Przekrycie & sklepienie krzyżowo-żebrowe wielopolowe [9] \\
\hline Konstrukcja i pokrycie dachu & dach wielopołaciowy [9] \\
\hline Łuk tęczowy & $\begin{array}{c}\text { ostrołukowa arkada z żebrem zaakcentowanym brązowym } \\
\text { kolorem wspartym na kompozytowym kapitelu filara [9] }\end{array}$ \\
\hline Dekoracja ścian & $\begin{array}{c}\text { na ścianach polichromie o motywach roślinnych i symboliczno- } \\
\text { religijnych [9] }\end{array}$ \\
\hline Dekoracja sklepień & $\begin{array}{c}\text { polichromia o motywach roślinnych [9]; wzdłuż ścian pas coko- } \\
\text { łowy z profilowanym gzymsem [9] }\end{array}$ \\
\hline Okna & duże ostrołuczne okna analogiczne jak w korpusie [9] \\
\hline Witraże & barwne witraże z postaciami biblijnymi [9] z lat 1900-1903 [9] \\
\hline
\end{tabular}

Przylegające do prezbiterium zakrystie przekryte są stropem płaskim [7], ich namiotowe dachy nakryte zostały dachówką. Każde z pomieszczeń doświetla maswerkowy okulus o szczeblinach promienistych, w tynkowanej profilowanej ramie ujętej ceglaną oprawą. Komunikację na zewnątrz zapewniają prostokątne przeprucia w profilowanych tynkowanych portalach [9].

Prosto zamknięty transept ma w nadchórzu trzy przęsła, w przyziemiu pięć (boczne skrzydła podzielone są na dwa przęsła, każde z nich trójpolowe). Komunikację między ramionami w podchórzu wyznaczają arkady o zamknięciach odcinkowych między kolumnami z kapitelami składającymi się z płaskich i piramidalnych warstw betonu. W nadchórzu przęsła rozdzielone są przez ostrołukowe arkady między filarami wiązkowymi analogicznymi jak w korpusie nawowym. Narożniki ramion są obustronnie ujęte dwuuskokowymi przyporami $\mathrm{z}$ betonowymi pulpitowymi kapnikami. Dekorację elewacji stanowi betonowy cokół z wysuniętym fartuchem, gzyms kordonowy na poziomie parapetu okna ostrołucznego i bogate zdobienia szczytu różnymi rodzajami fryzów arkadkowych o ostrych zamknięciach. W szczycie znajduje się także rozeta w tynkowanej opasce z motywem czteroliścia z okulusem wewnątrz [9]. Pozostałe elementy architektoniczne transeptu (tab.3).

W świątyni zachowało się pierwotne wyposażenie: ołtarz ufundowany przez rodzinę pastora Eugeniusza Biedermanna (obraz „Spotkanie Zmartwychwstałego z Marią Magdaleną" namalował w 1900 roku Wojciech Gerson), am- 
bona z fundacji rodzin Kessler, Melchier, Müller, Roland i Simon, ławki opłacone przez Jana Wende. Organy 31-głosowe wykonała firma braci Walter; $\mathrm{z}$ wyposażenia wymienić jeszcze musimy marmurową chrzcielnicę z początku $\mathrm{XX}$ wieku [1].

Tabela 3. Kościół Zbawiciela w Tomaszowie Mazowieckim. Charakterystyka transeptu

Table 3. The Saviour's Church in Tomaszów Mazowiecki. Characteristic of the transept

\begin{tabular}{|l|c|}
\hline \multicolumn{1}{|c|}{$\begin{array}{c}\text { Elementy } \\
\text { architektoniczne }\end{array}$} & Opis \\
\hline Szczyty & $\begin{array}{c}\text { trójkątny, zwieńczony wimpergą, podzielony na dwa poziomy ujęte po } \\
\text { bokach obeliskami nakrytymi piramidalnie o ściętych wierzchołkach; } \\
\text { obeliski stoją na szerokich, mocno profilowanych gzymsach, we- } \\
\text { wnętrzne są przedłużeniem masywnych ceglanych pilastrów [9] }\end{array}$ \\
\hline Przekrycie ramion & $\begin{array}{c}\text { w nawach bocznych empory, pod nimi sklepienie krzyżowe, nad em- } \\
\text { porami sklepienie krzyżowo-żebrowe, na skrzyżowaniu z nawą skle- } \\
\text { pienie gwiaździste [9] }\end{array}$ \\
\hline $\begin{array}{l}\text { Konstrukcja } \\
\text { i pokrycie dachu }\end{array}$ & $\begin{array}{c}\text { dach dwuspadowy kryty blachą ocynkowaną krzyżujący się z główną } \\
\text { kalenicą [9] }\end{array}$ \\
\hline Dekoracja ścian & $\begin{array}{c}\text { częś pod emporą tynkowana i pobiałkowana, nad emporą pola malo- } \\
\text { wane niało i żółto [9] }\end{array}$ \\
\hline Dekoracja sklepień & $\begin{array}{c}\text { pod empora sklepienie pobiałkowane, nad emporą zaakcentowane na } \\
\text { brązowo żebra sklepienne [9] }\end{array}$ \\
\hline Okna & $\begin{array}{c}\text { duże okno o zamknięciu ostrołucznym w tynkowanej profilowanej } \\
\text { oprawie, podzielone potrójnym laskowaniem na dwie części, tworzące } \\
\text { wewnętrzne okna podzielone również słupkiem; w zamknięciu we- } \\
\text { wnętrznych okien maswerki w kształcie pięciolistnej koniczyny; między } \\
\text { zamknięciami okien wewnętrznych w zamknięciu okna dużego maswerk } \\
\text { o kształcie podwójnego pięcioliścia koniczyny w okulusowej oprawie - } \\
\text { okno to doświetla część korpusu nad emporą; część pod emporą doświe- } \\
\text { tla triforium o odcinkowych zamknięciach w betonowej oprawie [9] }\end{array}$ \\
\hline barwne witraże z postaciami apostołów, ewangelistów i Jezusa [9] \\
\hline Witraże
\end{tabular}

Przejdźmy wreszcie do opisu fasady. Składa się ona z trzech części. Środkową zajmuje kilkukondygnacyjna wieża o wysokości około $60 \mathrm{~m}$, która w czasie budowy była najwyższym punktem w mieście [1]. Flankowana jest przedsionkami na planie leżących prostokątów wysuniętych poza lica ścian korpusu, w których umieszczono schody zapewniające komunikację z emporą organową i wyższymi poziomami wieży. Przyziemie wieży zajmuje kruchta o planie zbliżonym do kwadratu o ściętych narożnikach wewnętrznych, do której prowadzi prostokątne przeprucie drzwiowe umieszczone $\mathrm{w}$ ostrołucznej oprawie schodkowej wykonanej z kolumienek o zdobionych kompozytowych kapitelach. W tympanonie umieszczono maswerkowy rozetowy element trójliścia w okulusowej oprawie z barwnym geometrycznym witrażem, a trójkątny szczyt zwieńczono wimpergą. Duże okno nad portalem wejściowym ma profilowaną rozglifioną tynkową oprawę, na wysokości początku zamknięcia podzielone jest poziomym profilowanym laskowaniem, 
nad którym dano dwa maswerkowe wchodzące w siebie elementy pięcioliścia; część dolną podzielono laskowaniem na triforium i ostro zamknięto. Narożniki wieży do poziomu kalenicy przedsionków obustronnie oszkarpowano trójuskokowymi przyporami nakrytymi pulpitowymi kapnikami [9], a na kolejnym wyższym poziomie wieży ujętym poziomo profilowanymi gzymsami umieszczono kolisty zegar w otynkowanej kwadratowej oprawie, wykonany w firmie braci Meister w Berlinie, a fundowany przez F. Fremsdorfa [1]. Po bokach wieży na wysokości zegara dano ślepe zdobienia podobne jak z czoła wieży. W dolnej części fasady umieszczono betonowy cokół z wydatnym fartuchem, a na wysokości zamknięcia portalu tynkowany profilowany gzyms kordonowy. W najwyższym poziomie wieży z jej czterech stron znalazły się ostre okna w tynkowanej oprawie, w profilowanym rozglifieniu, zdobione w zamknięciu pięcioliściem, podzielone pionową laską na dwie ostrołuczne części i zakryte żaluzją [9]. Tę część kościoła zajmuje dzwonnica, a trzy stalowe dzwony odlane w Bochum w Westfalii ufundowała rodzina Knothe [1]. Wieżę nakryto hełmem iglicowym zwieńczonym krzyżem i kulą, a po jej bokach założono trójkątne szczyty, zwieńczone wimpergami. Podobnie ozdobiono fronty przywieżowych przedsionków $\mathrm{z}$ analogicznymi portalami i ostrołucznymi oknami, ale o mniejszej skali. Dodatkowo pas pod dachem dwuspadowym przedsionków udekorowano gzymsem arkadkowym o ostrych zamknięciach, a w szczytach z wimpergami okalających iglicę dano tynkową dekorację trójliścia [9]. W elewacji bocznej każdej z krucht przywieżowych znajduje się duże okno o ostrołukowym zamknięciu umieszczone w tynkowanym rozglifieniu, ujęte ceglaną oprawą, analogiczne jak okna naw bocznych. Podzielone jest laskowaniem, zdobione maswerkiem z wydatnym ukośnym piaskowcowym parapetem umieszczone nieznacznie wyżej od okien nawowych. Pod nim, w przyziemiu, znajduje się prostokątne okno w mocno profilowanej oprawie tynkowej z ukośnym parapetem, oddzielone ceglanym pasem od kołnierza cokołu [9].

W latach 1935-1936 wykonano elektryfikację i pierwsze prace konserwatorskie, w latach 1969-1970 miały miejsce kolejne prace renowacyjne, m.in. zamiana dachówki na blachę ocynkowaną. W latach 1986-1987 przeprowadzono renowację witraży [7].

Na koniec wróćmy jeszcze na chwilę do czasów erygowania parafii. Poświęcenia nowego kościoła w obecności 10 tysięcy wiernych dokonał 15 sierpnia 1902 roku proboszcz Eugeniusz Biedermann, a symbolicznego otwarcia drzwi dokonał Superintendent ksiądz Karol Gustaw Manitus [1, 2]; pierwsze kazanie wygłosił ksiądz Eugeniusz Biedermann [2]. Podkreślmy również, że kościoły neogotyckie katolickie i ewangelickie pod względem funkcji przestrzenno-użytkowej i architektonicznej się nie różnią, może dekoracje wnętrza u luteranów są skromniejsze, ale wyróżnikiem w kościołach ewangelickich jest obecność empory nad nawami bocznymi. 


\section{Literatura}

[1] Gwóźdź E., Tomaszów Mazowiecki - Zespół kościoła ewangelicko-augsburskiego (Karta ewidencyjna zabytków architektury i budownictwa),Piotrków Trybunalski 1997 (mps w WUOZ w Łodzi Delegatura w Piotrkowie Trybunalskim).

[2] Historia parafii w Tomaszowie Mazowieckim [w:] Parafia ewangelicko-augsburska w Tomaszowie Mazowieckim, www.tomaszow.luteranie.pl/historia (dostęp 9.05.2017).

[3] Kneifel E., Die Pastoren der Evangelisch-Augsburgischen Kirche in Polen. Ein biographisches Pfarrerbuchmiteinem Anhang, Eging [1967].

[4] Kneifel E., Geschichte der Evangelisch-Augsburgischen Kirche in Polen, Niedermarschacht über Winsen/Luhe [1964].

[5] Korczak Ziółkowski J., Tomaszów Mazowiecki - Kościół ewangelicki p.w. Św. Trójcy ob. polskokatolicki (Karta ewidencyjna zabytków architektury i budownictwa), Piotrków Trybunalski, 1991 (mps w WUOZ w Łodzi Delegatura w Piotrkowie Trybunalskim).

[6] Kurzer Abriss der Geschichte der Tomaszower Evangelisch-Augsburgischen Gemeinde, Tomaszów 1902.

[7] Stefański K., Tomaszów Mazowiecki - Ewang.-augsb. kościół parafialny p.w. Zbawiciela (Karta ewidencyjna zabytków architektury i budownictwa), Piotrków Trybunalski 1988 (mps w WUOZ w Łodzi Delegatura w Piotrkowie Trybunalskim).

[8] Tomaszów [w:] Słownik Geograficzny Królestwa Polskiego i innych krajów słowiańskich, t. 12, red. B. Chlebowski, Warszawa 1892, s. 371-374.

[9] Tomaszów Mazowiecki - dokumentacja fotograficzna własna (w archiwum autorów).

\section{EVANGELICAL CHURCHES IN TOMASZÓW MAZOWIECKI. ANALYSIS OF THEIR SPATIAL PROGRAM AND ARCHITECTURAL FEATURES}

\section{S u m m a r y}

The purpose of the article is to analyse the spatial program and architectural features of the two evangelical churches in Tomaszów Mazowiecki: the Church of the Holy Trinity and the Saviour's Church. The first one was built in the 1820s in the Square of the town, when the first members of evangelical church came to the newly created hamlet, where the textile industry started to be developed. It was built on a rectangular plan, with asemi-oval chapel to the north, used as a sacristy. Richly decorated south facade, directed to the square, has classicist features, grooved pilasters holding a tympanum represent provincial architecture (in a good sense). The interior was on three sides surrounded by galleries on wooden columns, what is a characteristic feature of evangelical churches. Unfortunately, the first decoration and equipment are not preserved. The church could accommodate 400 people, the number of them, which continued to increase, caused the necessity of building a new, large church at ul. św. Antoniego.The Neo-Gothic church was built between 1897 and 1899, by design of Paweł Hoffer. It is a stepped hall with the presbytery to the north-east. The facade has one tower between rectangular porches. The three-bay structure with buttresses is vaulted by groin and rib-groin vaults separated by the narrow pointed transverse arches. Elevations are decorated by cornices, small columns, blind windows, and in the windows 
there was used a mullion, a tracery and ornaments in the shape of a five-part leaf. Comparing this evangelical structure with catholic Neo-Gothic churches we have to say, that their spatial and architectural programs do not differ, possibly the decorations of the interiors of evangelical churches are simpler and their main feature are galleries in aisles.

Keywords: sacral architecture, Classicism, Neo-Gothic, Historicism

Przestano do redakcji: 09.06.2017 r.

Przyjęto do druku: 01.09.2017 r. 
